\title{
Negative Media Coverage and Corporate Social Responsibility _ Empirical Evidence from Chinese A - Share Listed Companies
}

\author{
Wang Bo \\ School of Economics and Management, Southwest Jiaotong University, Chengdu, China
}

Email address:

boy5240@163.com

To cite this article:

Wang Bo. Negative Media Coverage and Corporate Social Responsibility _ Empirical Evidence from Chinese A - Share Listed Companies. International Journal of Business and Economics Research. Vol. 6, No. 4, 2017, pp. 61-66. doi: 10.11648/j.ijber.20170604.14

Received: June 21, 2017; Accepted: July 10, 2017; Published: July 19, 2017

\begin{abstract}
This paper takes the listed companies of Shanghai and Shenzhen A-shares as the object of research from 2013 to 2015, and makes an empirical test on the effect of corporate social responsibility of listed companies from two aspects: Negative media coverage and property rights. The results of the research show that: The negative reports of media are positively related to the fulfillment of corporate social responsibility, the more negative reports of media, the higher the performance level of corporate social responsibility of listed companies; There is a positive correlation between the nature of property rights and the performance level of corporate social responsibility, the performance of corporate social responsibility of listed companies with state-owned enterprises is better; The total number of media reports is positively related to the fulfillment of corporate social responsibility, the more the number of media reports, the better the corporate social responsibility.
\end{abstract}

Keywords: Negative Media Coverage, Corporate Social Responsibility, Property Right of Enterprise

\section{Introduction}

The fulfillment of corporate social responsibility has been controversial in academia, and there are different views. Waddock and Graves (1997) summarize three perspectives on the relationship between social responsibility and firm performance: Positive correlation, negative correlation and irrelevance. That is a positive correlation is to support enterprises to fulfill their social responsibilities [1]. By the study of the researcher Deng Dongmei, it can be seen that the social responsibility information can make the investor more fully understand the enterprise, has certain decision value, and the disclosure of the enterprise information and the fulfillment of the corporate social responsibility can stimulate the enterprise performance [2]. The Porter and Kramer (2002) have shown that negative media coverage can promote corporate social responsibility and enhance the trust of investors, so that enterprise can be more stable and healthy and sustainable development of competitive advantage. Consumers, investors and other stakeholders interested in corporate social responsibility information, integrated Zhang and other scholars of the study, the results show that the relevant stakeholders in addition to concerned about the company's product results of their own information, but also on corporate social responsibility information Interests [3]. Li Guoping, Wei Xiaoqian research shows that large domestic enterprises have begun to pay attention to consumers, investors and other stakeholders on the information needs, and actively from all channels to disclose the implementation of social responsibility, timely release of corporate annual report [4]. Shen Ge and other research shows that enterprises in order to improve the relationship with the stakeholders will meet the interests of stakeholders in the implementation of corporate social responsibility curiosity, so companies will take the initiative to corporate information close to the basic content of social responsibility to strengthen the social responsibility information Of the disclosure [5]. Qian Yu's research pointed out that a responsible and promising business, commitment to fulfill corporate social responsibility is necessary, the development of enterprises can not do without the assessment of corporate performance, and corporate performance and corporate social responsibility was positively related, so the enterprise Development to meet the corporate social responsibility 
content, a positive response to the requirements [6]. Wang Fan's report pointed out that corporate social responsibility negative news once the media real-time reports, significantly improve the quality of corporate accounting information, media negative reports on the implementation of corporate social responsibility has a positive role in promoting, to improve corporate earnings [7].

\section{Theoretical Analysis and Hypothesis}

\subsection{The Impact of Negative Report on Social Responsibility}

The more the number of media reports, the better the performance of corporate social responsibility, the higher the level of disclosure, and showed a significant positive correlation (Wang, 2016) [8]. The governance role of the company is not only through the improvement of other governance mechanisms to play, but more importantly through the negative reports of the results (Zheng Zhigang, 2011) [9]. Huang Hui research results show that the negative media reports on the market a negative response, the more the number of the worse, the more able to reduce the performance of enterprises, which will in turn improve the business to fulfill their own social responsibility [10]. These are enough to explain the negative media coverage as a corporate governance mechanism outside the law, corporate social responsibility is the most important control factors, but also the most important conditions for corporate social responsibility. The more negative reports of the media, the more conducive to the next period of listed companies to enhance the transparency of information disclosure, thereby improving the company's corporate social responsibility to fulfill, and ultimately improve the company's governance role (Zheng Tao, 2010) [11]. These findings suggest that negative media coverage is important for companies to fulfill their social responsibilities. Based on the above information, this paper makes the following assumptions:

Hypothesis 1: Negative media coverage has a significant positive correlation with corporate social responsibility. The more negative media reports, the higher the level of corporate social responsibility.

\subsection{The Impact of Property Rights on Social Responsibility}

The nature of property rights of enterprises also has a greater impact on the implementation of social responsibility. The ethical ontology of corporate social responsibility is composed of the nature of the property rights of enterprises. The corporate mission is the intrinsic value carrier of corporate social responsibility. The most critical and effective is the social responsibility of any enterprise property rights. Are likely to be "good" in the name of evil [12]. The nature of the property rights of enterprises determines the way of dealing with negative reports. The state-owned enterprises as the economic pillar of the capitalist market are more stringent than the supervision of the state government by the government, and the political intervention and policy pressure is higher for the social security. Better development of the company, to attract investment, state-owned enterprises will effectively fulfill their responsibilities to improve the credibility of enterprises (Xie Lin, 2016) [13]. The study found that through the implementation of social responsibility can directly improve the business and consumers, investors and other stakeholders related to the relationship, but also can be indirect to the extent of the use of relevant industries or government policies to improve the capitalist market and government The relationship [14]. The study shows that the recognition of capital market is related to the fulfillment of corporate social responsibility, which is linked to the property rights of enterprises. The more government intervention, the higher the quality and the higher degree of recognition [15]. The Therefore, enterprises in order to obtain a more stable market position and promote the sustainable development of enterprises, with the support of the national government, the need to further enhance their own business value and maintain friendly relations with the government and the community. Based on the above analysis, another hypothesis is proposed:

Hypothesis 2: The nature of the enterprise property determines the degree of corporate social responsibility. State-owned enterprises are more sensitive to negative media coverage and higher levels of social responsibility.

\section{Empirical Study}

\subsection{Selection and Study of Variables}

(1) social responsibility (CSR)

Corporate social responsibility must include two elements: Firstly, the implementation of corporate social responsibility should be voluntary; Secondly, enterprises not only to corporate shareholders to fulfill their social responsibilities, but also on the community, consumers and suppliers and other related interests Party to fulfill social responsibility [16]. Based on the existing research, this paper uses Runen Global's social responsibility report rating score as an index to evaluate corporate social responsibility. The performance rating is based on the rating of the sample company from 2013 to 2015, and the higher the rating score, the better the performance of the corporate social responsibility and the more proactive.

(2) negative coverage ( $\mathrm{nr}$ )

Negative coverage of the media can play a role in the company's governance, mainly because the negative reports can affect the economic behavior of enterprises, but also because of the negative characteristics of the media reported that the impact of different effects on the enterprise economy [17]. The number of negative reports in this article comes from the "China's important newspaper full-text database", screening from 2012 to 2014,336 sample companies, the final sample size of 1008 Shenzhen A shares listed companies related to the report, specifically from eight Mainstream newspapers: Securities Daily, First Financial Daily, China Securities Journal, Securities Times, Shanghai Securities News, Century Economic Report, China Business News and Economic Observer. The number of negative reports is large, 
due to manual screening, heavy workload, time-consuming, in view of the final stability test, manual statistics of the total number of media reports of the various samples.

(3) control variables (control variables)

Custom indicators cannot always avoid the interference of other factors, the control variable intake can just simplify the process, according to conventional estimates, through simulation verification, making the assumption that the custom indicators more effective and superior [18]. It has been shown that the enterprise's life span, firm size, corporate property rights, earnings per share and asset-liability ratio also have a significant impact on corporate social responsibility. In this paper, the control variables, screening Wande database (wind) in the sample company's data as a study of data validation. See Table1 for details.

Table 1. Description of the study variables.

\begin{tabular}{lll}
\hline Variable name & Variable code & Variable definitions \\
\hline Corporate Social Responsibility & CSR & Runling Global Database's Social Responsibility Rating Score \\
Negative coverage & NR & From 2012 to 2014, "China's important newspaper full-text database" \\
Time to market & YOL & Based in 2013, 2014 and 2015 \\
Enterprise scale & SIZE & Self - heating logarithm of registered capital of listed companies \\
Property rights of enterprises & STATE & If the actual holding company is a state-owned property company, STATE assigned to 1, otherwise 0 \\
Earnings per share & EPS & The value is derived from the company's annual stock returns from the Vander database \\
Assets and liabilities & ALR & The value comes from the company's annual report \\
year & YEAR & This paper studies the design span of four years as a dummy variable \\
industry & InD addition to the real estate industry, but also related to the construction industry and other dummy \\
\hline
\end{tabular}

Based on the above variables, for the verification hypothesis, the regression model is constructed as follows:

Model 1: $C R S=\beta_{0}+\beta_{1} N R+\beta_{2} Y O L+\beta_{3} S I Z E+\beta_{4} S T A T E+\beta_{5} E P S+\beta_{6} A L R+\beta_{7} Y E A R+\beta_{8} I N D+\varepsilon$

Model 2: $C R S=\beta_{0}+\beta_{1}$ TMC $+\beta_{2} Y O L+\beta_{3} S I Z E+\beta_{4} S T A T E+\beta_{5} E P S+\beta_{6} A L R+\beta_{7} Y E A R+\beta_{8} I N D+\varepsilon$

\subsection{Sample Data Processing}

First select the Shanghai and Shenzhen A-share listed companies, excluding the financial and insurance industry and ST and *, the beginning of the company, the final choice of 336 listed companies for the study, the data sample volume of 1008. And then screened the sample company in Riverson Global Ratings to score in 2013, 2014 and 2015. In contrast to the sample companies, we found the total number of media reports in the eight major newspapers in 2012, 2013, and 2014, and screened out the number of negative reports, and found them in the Wind database. 336 sample companies in 2013, 2014 and 2015 corresponding to the listed years, the size of the enterprise, the nature of property rights, earnings per share, asset-liability ratio data. After finding the verification data, use SPSS22.0 version of the statistical software for testing and analysis.

\subsection{Test Analysis}

\subsubsection{Descriptive Statistics}

Table 2 is the result of the descriptive statistics of the sample size. The maximum score of social responsibility is 84.4985 , the minimum is 18.5681 , the average is 42.5190 , which indicates that the listed company has low level of social responsibility, (The corresponding CSR value), the average value of 18.904 (corresponding to the value of CSR), the maximum value of 44 (corresponding to the CSR (the corresponding CSR value), the minimum value is 44 (corresponding to the CSR), the standard value is 12.0727 , The maximum number of media reports is 0 , the maximum value is 319 , the standard deviation is 30.4312 , also shows that the total number of media coverage of the social responsibility of the social responsibility of the social responsibility of the social responsibility of the Performance to promote the role, that is, the more the number of reports, the corresponding corporate social responsibility to perform the better.

Table 2. Variable descriptive statistics.

\begin{tabular}{|c|c|c|c|c|c|}
\hline Variable & $\mathbf{N}$ & Minimum value & The maximum value & Average & standard deviation \\
\hline CSR & 1008 & 18.5681 & 84.4985 & 42.5190 & 12.0727 \\
\hline NR & 1008 & 0 & 44 & 7.98 & 6.8839 \\
\hline TMC & 1008 & 0 & 319 & 18.904 & 30.4312 \\
\hline YOL & 1008 & 1 & 25 & 11.908 & 5.6969 \\
\hline SIZE & 1008 & 18.7282 & 25.5196 & 21.2435 & 1.1974 \\
\hline STATE & 1008 & 0 & 1 & 0.238 & 0.4261 \\
\hline EPS & 1008 & -2.29 & 4.63 & 0.4198 & 0.5723 \\
\hline
\end{tabular}

\subsubsection{Regression Analysis}

(1) full sample regression

The results of the full sample regression are listed in Table 3.
The regression results show that negative reporting (NR) is significant at $1 \%$ level and is positively related to corporate social responsibility (CSR), indicating that the higher the number of negative reports, the better the corporate social 
responsibility of the sample company Corporate social responsibility is not only subject to the interests of consumers and other stakeholders, but also focus on accepting the negative reports of the media supervision, support the hypothesis 1 .

As can be seen from Table 3, the number of years of listing (YOL) is significant at $10 \%$ level, and there is a negative correlation with CSR (CSR), indicating that the shorter the listing period, the higher the level of corporate social responsibility (SIZE) is significant at $1 \%$ level, and has a positive correlation with CSR (CSR), which indicates that the larger the firm is, the better the corporate social responsibility is. The nature of the enterprise property (STATE) is at $1 \%$ (EPS) is positively correlated with corporate social responsibility (CSR), indicating that the nature of property rights for state-owned enterprises listed companies have higher levels of corporate social responsibility; earnings per share (EPS) at 10\% level, with corporate social responsibility (CSR) is positively correlated with corporate social responsibility (CSR), indicating that the higher the earnings per share, the higher the level of corporate social responsibility; the asset-liability ratio (ALR) is significant at 5\% The lower the debt ratio, the better the corporate social responsibility of listed companies.

From the results of the regression results in Table 4, it can be seen that the negative coverage of the total number of reports (negative / total) of the selected companies in this paper is significant at $1 \%$ level and positively correlated with corporate social responsibility (CSR) In the media reports, the more negative reports, corporate social responsibility to perform the better, once again verify the hypothesis 1 . (YOL) was significant at 5\% level, and there was a negative correlation with CSR (CSR), indicating that the higher the listing period, the higher the level of corporate social responsibility of the listed companies. The firm size (SIZE) (STATE) is significant at the level of $1 \%$, and it is related to corporate social responsibility (CSR), which is related to corporate social responsibility (CSR), which is significant in relation to corporate social responsibility (CSR), which shows that the bigger the firm is, the better the corporate social responsibility is. (EPS) is significant at $1 \%$ level and positively correlated with CSR (CSR), indicating that each of the listed companies has a positive correlation with the corporate social responsibility (CSR) of the state-owned enterprises. (ECR) is significant at the level of $5 \%$, and there is a negative correlation with CSR (CSR), indicating that the lower the asset-liability ratio of the listed companies in the enterprise The better the social responsibility is fulfilled.

Table 3. Sample regression results.

\begin{tabular}{lll}
\hline \multirow{2}{*}{ variable } & Model & \\
\cline { 2 - 3 } & coefficient & T value \\
\hline C & - & -2.961 \\
NR & $0.246 * * *$ & 7.949 \\
YOL & $-0.049 *$ & -1.797 \\
SIZE & $0.278 * * *$ & 8.672 \\
STATE & $0.178 * * *$ & 6.276 \\
EPS & $0.051 *$ & 1.871 \\
\hline
\end{tabular}

\begin{tabular}{lll}
\hline \multirow{2}{*}{ variable } & Model & \\
\cline { 2 - 3 } & coefficient & T value \\
\hline ALR & $-0.065^{* *}$ & -2.274 \\
YEAR & control & control \\
IND & control & control \\
F value & $63.674^{* * *}$ & \\
Adj. R2 & 0.272 & \\
\hline
\end{tabular}

Note: $* * *$ indicates significant at $1 \%$ level; $* *$ indicates significant at $5 \%$ level; * indicates significant at $10 \%$ level.

Table 4. Sample regression results.

\begin{tabular}{lll}
\hline \multirow{2}{*}{ variable } & Model & \\
\cline { 2 - 3 } & coefficient & T value \\
\hline C & - & -7.364 \\
Negative / total & $0.110^{* * *}$ & 3.905 \\
YOL & $-0.062 * *$ & -2.211 \\
SIZE & $0.413 * * *$ & 13.710 \\
STATE & $0.203 * * *$ & 7.064 \\
EPS & $0.076^{* * *}$ & 2.712 \\
ALR & $-0.073 * *$ & -2.516 \\
YEAR & control & control \\
IND & control & control \\
F value & $53.291 * * *$ & \\
Adj. R2 & 0.238 & \\
\hline
\end{tabular}

Note: $* * *$ indicates significant at $1 \%$ level; $* *$ indicates significant at $5 \%$ level; * indicates significant at $10 \%$ level.

\section{(2) grouping regression}

In order to better test the nature of corporate property rights and corporate social responsibility to fulfill the relationship between the two, this paper used to test the return group. The nature of the property rights of enterprises for the state-owned enterprises assigned to the value of non-state-owned private enterprises assigned to 0 , divided into two groups to get the results of Table 5. As can be seen from the list, both the state-owned enterprise group and the private enterprise group, the negative coverage (NR) coefficient is significant at $1 \%$ level, and with corporate social responsibility (CSR) was positively correlated, from Table 5 (NR) regression coefficient of 0.417 is higher than that of private enterprise group (NR) regression coefficient of 0.366 , which shows that the nature of property rights of enterprises is the level of corporate social responsibility of state-owned enterprises High, once again supported to verify hypothesis 2 .

Table 5. Group regression test results.

\begin{tabular}{lllll}
\hline \multirow{2}{*}{ variable } & \multicolumn{2}{l}{ Property rights (1) } & \multicolumn{2}{l}{ Property rights (0) } \\
\cline { 2 - 5 } & coefficient & T value & coefficient & T value \\
\hline NR & $0.417 * * *$ & 7.028 & $0.366^{* * *}$ & 10.909 \\
YEAR & control & & control & \\
IND & control & & control & \\
F value & $25.253 * * *$ & & $30.081 * * *$ & \\
Adj. R2 & 0.340 & & 0.159 & \\
\hline
\end{tabular}

Note: $* * *$ indicates significant at $1 \%$ level; $* *$ indicates significant at $5 \%$ level; * indicates significant at $10 \%$ level.

\subsubsection{Robustness Test}

This paper also selected 336 sample companies in 2012 2014, the total number of media coverage as another independent variable, start robustness test. The relevant data 
from the China Knowledge Network, "China's important newspaper full-text database" in eight mainstream newspapers (Securities Daily, First Financial Daily, China Securities Journal, Securities Times, Shanghai Securities News, Century Economic Report, China Business News and Economic Observer ) Shows the total number of negative reports reported manually. At the same time, this article also uses the Google search engine for related retrieval and testing, on this basis to get the same basic conclusions (this article is not a statistical report). The test results are shown in the following table.

As can be seen from Table 6, the regression results of Model show that the total number of media reports (TMC) is significant at the $5 \%$ level and positively correlated with CSR (CSR), indicating that the total number of media reports The higher the level of corporate social responsibility of the sample company, proving that the corporate social responsibility of the listed company is subject to the supervision of the media reports, and once again supports the hypothesis. (YOL) is significant at 5\% level, and there is a negative correlation with CSR (CSR), indicating that the shorter the listing period, the better the corporate social responsibility of the listed company. The firm size (SIZE) (CSR) is positively correlated with corporate social responsibility (CSR), indicating that the larger the firm is, the better the corporate social responsibility is. The nature of the property (STATE) is significant at the level of $1 \%$, and the corporate social responsibility (CSR) (EPS) is significant at the level of $5 \%$, which is related to corporate social responsibility (CSR) (CSR) and corporate social responsibility (CSR), which is a significant correlation between the property rights and the property rights of state-owned enterprises. (ALR) is significant at 5\% level, and is negatively correlated with corporate social responsibility (CSR), indicating that the higher the asset-liability ratio, the higher the value of the assets and liabilities Low sample of listed companies with better corporate social responsibility.

Table 6. Coefficients.

\begin{tabular}{lll}
\hline \multirow{2}{*}{ variable } & Model & \\
\cline { 2 - 3 } & coefficient & T value \\
\hline C & - & -5.262 \\
TMC & $0.057^{* *}$ & 1.872 \\
YOL & $-0.057^{* *}$ & -2.022 \\
SIZE & $0.366^{* * *}$ & 11.332 \\
STATE & $0.201^{* * *}$ & 6.922 \\
EPS & $0.068^{* *}$ & 2.432 \\
ALR & $-0.072^{* *}$ & -2.463 \\
YEAR & control & control \\
IND & control & control \\
F value & $50.747^{* * *}$ & \\
Adj. R2 & 0.229 & \\
\hline
\end{tabular}

Note: $* * *$ indicates significant at $1 \%$ level; $* *$ indicates significant at $5 \%$ level; * indicates significant at $10 \%$ level.

The results of the robustness test showed that the total number of media reports and the negative reports of the media were positively correlated with the fulfillment of corporate social responsibility. Under this condition, the nature of the property rights of the enterprises was the performance of the corporate social responsibility of the listed companies Level is still higher than the private enterprises, which can be seen, media reports as a legal mechanism, the corporate governance has a significant role.

\section{Conclusions}

This paper takes the listed companies of Shanghai and Shenzhen A shares in 2013 and 2015, and makes an empirical study on the negative reports of the media, the nature of property rights and the fulfillment of corporate social responsibility. The results of the final empirical study show that: (1) negative reports of media and corporate social responsibility of listed companies have a significant positive correlation, the media reported that the more negative coverage of social responsibility of listed companies was significantly higher than the negative media coverage the company. The media reported that the company involved in the listed years, the size of the enterprise, the nature of property rights, earnings per share and asset-liability ratio is the most basic corporate social responsibility information content, media reports as a company outside the legal system to curb corporate social responsibility The risk of unknown factors in the process, thereby enhancing the performance of corporate social responsibility; business investors, consumers, suppliers and other stakeholders can be negative reports through the media to improve the understanding of enterprise information, making the enterprise information more Transparent. (2) The total number of media reports is positively related to the fulfillment of corporate social responsibility, that is, the higher the total number of media reports, the better the social responsibility of the enterprise. The more the media reported the more listed companies, the higher the degree of government attention, the more stringent market competition, it is well known that the market is very important in the allocation of resources, based on the development needs of enterprises will take the initiative to fulfill social responsibility to obtain resources. (3) The nature of enterprise property rights has a significant positive correlation with the performance of corporate social responsibility, and the nature of corporate property rights is the performance level of corporate social responsibility of state-owned enterprises listed companies is higher than that of private enterprises. Thus, in the property rights of state-owned enterprises, the media negative reports to promote the implementation of corporate social responsibility is more effective, to strengthen the governance role of the company.

\section{References}

[1] Vinegar Weihua, Li Peigong. Media supervision corporate governance empirical research. Nankai management review, 2012, pp. 33-42.

[2] Deng Dongmei. Corporate Social Responsibility and Enterprise Performance Analysis. Technology Monthly, 2005, pp. 116-117. 
[3] Zhang Xianhua, Kong Long. Negative events in the corporate social responsibility performance insurance effect. Economic Research Reference, 2013, pp. 92-94.

[4] Li Guoping, Wei Xiaoqian. Connotation, Measurement and Economic Consequences of Corporate Social Responsibility: A Summary of Research on Corporate Social Responsibility Theory Abroad [J]. Accounting Research, 2014, pp. 33-40 + 96.

[5] Shen Yi, Xu Guanghua, Wang Zhiyan. Ouristic Corporate Social Responsibility Information Disclosure of "Words and deeds" Evolutionary Framework in Large Data Environment. Accounting Research, 2014, pp. 29-36+96.

[6] Qian Yu. Typical analysis of corporate social responsibility and corporate performance - based on stakeholder perspective. Enterprise Economy, 2013, pp. 79-82.

[7] Wang Fan. Corporate social responsibility of the negative media reports affect the quality of accounting information. Finance and Trade Research, 2016, pp. 148-156.

[8] Wang Yue. The relationship between media coverage and social responsibility information disclosure. Chongqing Technology and Business University, 2016.

[9] Zheng Zhigang, Ding Dong, Wang Changyun. Negative coverage of the media, manager's reputation and corporate performance improvement - Evidence from China's listed companies. Finance Research, 2011, pp. 163-176.
[10] Huang Hui. Media negative reports, market response and business performance. China Soft Science, 2013, pp. 104-116.

[11] Zheng Tao. Media coverage and capital market development. Southwest University of Finance and Economics, 2010.

[12] Li Lanfen. Enterprise nature and corporate social responsibility. Xuehai, 2008, pp. 174-178.

[13] Xie Lin. Corporate social responsibility, property rights and corporate value. Shanxi University of Finance and Economics, 2016.

[14] Su Rui core, Zhong Wei Zhou. Social responsibility embedded in the nature and objectives of private enterprises and the realization of the path. Management modernization, 2014, pp. 66-68.

[15] Li Yue-dong, Zhang Hui-qin. Property Nature, Corporate Social Responsibility and Capital Market Recognition. Macroeconomic Research, 2010, pp. 48-52 + 63 .

[16] Li Guoping, Wei Xiaoqian. Connotation, Measurement and Economic Consequences of Corporate Social Responsibility A Summary of Research on Corporate Social Responsibility Theory Abroad. Accounting Research, 2014, pp. 33-40 + 96 .

[17] Huang Hui. Media negative reports, market response and business performance. China Soft Science, 2013, pp. 104-116.

[18] Zhang Quanling, Huang Qizhen. Performance Evaluation of Multivariable Control System Based on User-defined Index. Control and Decision, 2011, pp. 1117-1120. 